\title{
Typology of Breeding Sites and Species Diversity of Culicids (Diptera: Culicidae) in Akanda and its Environs (North West, Gabon)
}

\author{
Richard Pamba, Aubin A. Koumba, Christophe R. Zinga-Koumba, Silas L. Sevidzem, Alexis \\ Mbouloungou, Lauriane L. Yacka, Luc S. Djogbenou, Jacques F. Mavoungou, and Bertrand M'Batchi
}

\section{ABSTRACT}

The typology of larval habitats and the species diversity of culicids were conducted in the Akanda and its environs by collecting mosquitoe larvae and nymphs present in water collections, from May to June 2019. A total of 334 breeding sites of which 158 positive $(47.31 \%)$ and 176 negative $(52.69 \%)$ were identified. Water storage media such as: barrels $(n=95 ; 28.44 \%)$, puddles $(n=73 ; 21.86 \%)$, ponds $(n=47 ; 14.07 \%)$, tires $(n=31 ; 9.28 \%)$ and drains $(n=22$; $6.59 \%$ ) were the most frequent types of breeding sites. In addition, 1549 mosquitoe larvae were collected, of which $59.39 \%$ belong to the sub-family Culicinae and $\mathbf{4 0 . 6 1 \%}$ belong to the sub family Anophelinae. After rearing, 790 adults were obtained and divided into 8 species, including Aedes albopictus, Aedes aegypti, Anopheles gambiae s.l., Anopheles pharaoensis, Culex tigripes, Culex decens, Culex quinquefasciatus, and Mansonia uniformis. Although preliminary, this information on the culicid fauna could be useful for the implementation of appropriate control strategies in the study area. Likewise, the presence of Anopheles gambiae s.l. in this area requires that additional studies on its resistance to insecticides be conducted as recommended by the World Health Organization.

Keywords: Typology, breeding sites, species diversity, mosquitoes, Akanda, Gabon
Published Online: March 28, 2020

DOI: $10.24018 / 2020.1 .1 .13$

\section{R. Pamba}

Ecole Doctorale des Grandes Ecole de Libreville (EDGE), Gabon. (richard_pamba@yahoo.com)

\section{A.A. Koumba}

University of Abomey-Calavi (UAC), Bénin.

(aubinho25@yahoo.fr)

C. R. Zinga-Koumba

Institut de Recherche en Ecologie Tropicale (IRET), Gabon. (zinga.koumba39@yahoo.com)

S.L. Sevidzem*

Ecole Doctorale des Grandes Ecole de Libreville (EDGE), Libreville, Gabon

(sevidzem.lendze@gmail.com)

*Corresponding Author

A. Mbouloungou

Université Omar Bongo (UOB), BP: 17004 Libreville, Gabon.

(ambulungu@yahoo.fr)

L. L. Yacka

Centre International de Recherches Médicales de Franceville (CIRMF), Gabon .

(laurhy6@gmail.com)

L. S. Djogbenou

University of Abomey-Calavi (UAC), 05 BP : 1604 Cotonou, Bénin.

(1djogbenou22002@yahoo.fr)

J.F. Mavoungou

Institut de Recherche en Ecologie Tropicale (IRET), BP: 13354 Libreville, Gabon.

(mavoungoujacques@yahoo.fr)

B. M'batchi

Université des Sciences et Techniques de Masuku (USTM), BP: 941 Franceville, Gabon.

(mbatchibertrand@yahoo.fr)

\section{INTRODUCTION}

Malaria remains by far the most widespread parasitic disease in the intertropical world, and particularly in subSaharan Africa [1,2]. According to the World Health Organization (WHO), malaria affected nearly 228 million people worldwide in 2019 compared to 219 million in 2017 with 405,000 human losses [3]. Among the deaths attributable to this parasitosis, 67\% (272,000) involved children under the age of 5 (WHO, 2019). In addition, Africa remains the continent most affected by this disease with $93 \%$ (213 millions) of malaria episodes and $94 \%$ of deaths [3].

Besides this parasitosis, arboviruses such as dengue, chikungunya, yellow fever and Zika fever, threaten 831 millions people worldwide, including $70 \%$ of the African population [4]. These diseases represent a major scourge to the health of human populations [5], [6], [7].

In Gabon, vector-borne diseases represent public health problems $[8,9]$. Referring to the National Health Information System (NHIS), malaria was the cause of 153,666 cases of consultation and 160 deaths recorded in health facilities in 2017 [10]. According to Leroy et al. [11], the 2007 Chikungunya epidemic caused nearly 20,000 cases in the country.

Also, these diseases, notably malaria, appear as one of the main obstacles on economic development in Gabon with relatively high cases of death and associated school and professional absenteeism [12]. The fight against these vectorborne diseases is essentially based on the control of vector populations. Indeed, vector control is one of the effective 
approaches to reduce the incidence of a disease in endemic areas. However, the effectiveness of this method requires an up-to-date entomological database. Indeed, the work conducted by Akono et al. [13] has shown that the establishment of an effective vector control method requires, for a given eco-climatic aspect, a good knowledge of the ecology of the vectors, in particular the identity and the bioecology of the vector mosquitoes and the characterization of their breeding sites. However, such knowledge is not available in the majority of localities in Gabon.

It is in this context that a preliminary entomological survey was conducted in Akanda and its environs, located in a degraded forest area, at $30 \mathrm{~km}$ from the city of Libreville, capital of Gabon. This town, created in 2013, has been subject to a significant urban dynamics associated with an increase in population. The installation of infrastructures and the construction of new human dwellings have strongly modified the natural landscape of this locality thus causing important disturbances among the populations of vectors.

The purpose of this study was to identify the different types of mosquitoe breeding sites, to determine the species diversity of Culicidae and to characterize the larval breeding sites of these insects in Akanda and its surroundings.

\section{MATERIALS AND METHODS}

\section{A. Study Area}

This study was conducted from May to June 2019 (rainy season) in the city of Akanda $\left(0^{\circ} 30^{\prime} 00^{\prime \prime} \mathrm{N} ; 09^{\circ} 30^{\prime} 00^{\prime} \mathrm{E}\right)$, a sub-urban area located in the northern periphery of the city of Libreville, capital of Gabon (Fig. 1). This area was declared as a municipality in 2013. Akanda covers an area of 45,482 hectares and is part of the departement du KomoMondah, in the province de l'Estuaire. It includes two boroughs divided into 15 districts [14]. There are several socio-economic activities including trading, sports, health, education, and tourism.

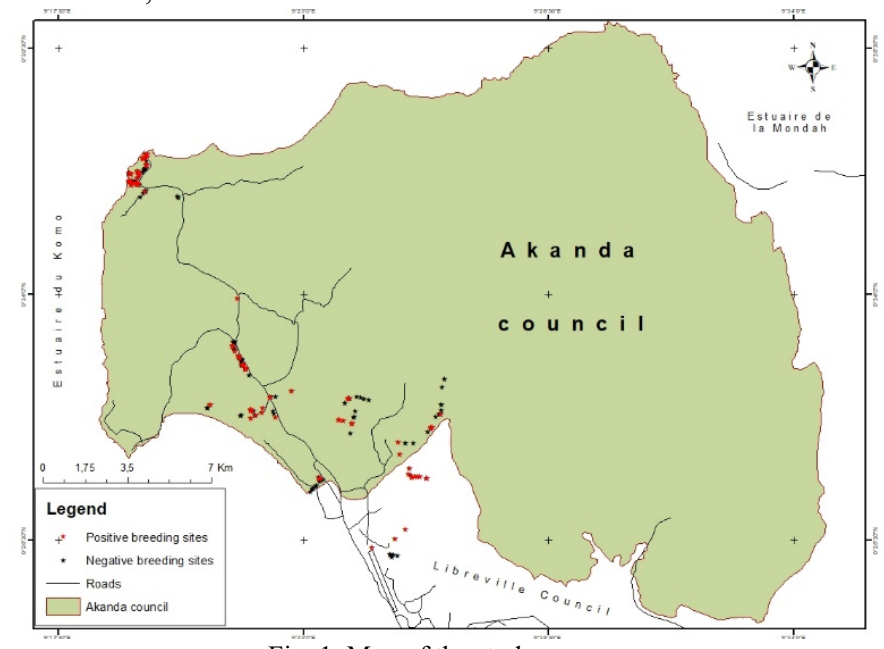

Fig. 1. Map of the study area.

From a climatic point of view, Akanda has an equatorial climate, with humidity between $85 \%$ and $100 \%$ in the rainy season [15]. It is marked by an alternation of four seasons, namely: a short dry season (from December to January), a long rainy season (from February to May) with high rainfalls, a long dry season (from June to September) and a short rainy season (October to November). This area experiences heavy rainfall with nearly 2,000 to $3,800 \mathrm{~mm}$ on average per year [15]. The average annual temperature is $26^{\circ} \mathrm{C}$ [15].
At the topographic level, Akanda is characterized, as a whole, by a flat relief with a predominance of plains. It lays on an uneven oro-hydrographic complex, endowed with multiple hills and valleys crossed by numerous rivers in the estuaire du Komo river [15]. In addition, the Akanda area has diversified flora and fauna colonizing the coastal forests and mangroves of Pongara National Park, Akanda National Park, and the Raponda Walker Arboretum. The vegetation in this area is deeply threatened by the current urban extension. According to the 2013 General Population and Housing Census (GPHC), this city has about 34,548 inhabitants distributed unevenly [16].

\section{B. Identification of Breeding Sites in the Study Area}

Mosquitoe breeding sites were surveyed in several places in Akanda, including: Marseille Mveng-Ayong, Premier Campement Makwengue, Cap-Estérias, Sablière, Avorbam, Angondjé Centre Amissa, Cap Caravane, Entraco, and Okala. The choice of these sites was guided by their ecological profile and the structuring of their landscape. These surveys were conducted during the rainy season, from May to June 2019. The survey consisted of direct observation of the presence or not of the pre-imaginal stages of mosquitoes [17]. All breeding sites likely to contain immature stages of mosquitoes were geo-located using the Garmin GPSMAP 62st device [18]. Other information concerning the identified breeding sites (type of water collection, origin of the water, presence of larvae or nymphs of mosquitoes) was noted in order to better characterize them.

\section{Sampling of Immature Stages of Mosquitoes}

Mosquitoe larvae and nymphs were collected during the study period from the different sites chosen, using the "dipping" method [17], [19], [20]. Each sample was transferred to labeled trays, using $300 \mathrm{ml}$ entomological pipettes. Subsequently, all the trays were put in coolers and transported to the insectarium of the Vector Ecology Laboratory (LEV) of the Research Institute in Tropical Ecology (IRET-CENAREST) for the rearing.

\section{Rearing Of Mosquitoe Larvae and Pupae}

In the laboratory, the different larvae collected were sorted and counted by sub-family (Anophelinae or Culicinae). They were then raised in plastic trays placed on the palliasse and covered with a piece of mosquitoe net to avoid possible egg-laying of other mosquitoes and the escape of adult mosquitoes in case of emergence. These larvae were fed every day with fish food (Sera Vipagran) [21]. The water in each tray (the water from the original breeding sites) was changed once every three days to avoid death by asphyxiation of the larvae further to the decomposition of food.

In addition, all the nymphs obtained were sampled daily and placed in 0.251 plastic cups containing water from the breeding sites. These cylindrical cups were placed in emergence cages covered with a mosquitoe net. The adult mosquitoes obtained from these nymphs were killed using an insecticide spray (Baygon) for their morphological identification.

\section{E. Morphological Identification of Adult Mosquitoes}

The adult mosquitoes that emerged from the nymphs were identified on the basis of the morphological criteria using a dissecting microscope and the taxonomic key of Central African mosquitoes by Baldacchino and Paupy [22], and the ORSTOM software for Culicidae identification. 


\section{F. Data Analysis}

Data on breeding sites, larvae and adult mosquitoes were entered and organized in the Excel 2013 spreadsheet. This spreadsheet allowed us to calculate the numbers and percentages of adults and immature stages of mosquitoes, and to produce tables and graphs. Moreover, the GPS points of the study sites were integrated into ArcGIS 10.2 for the elaboration of the map of the study area.

\section{RESULTS}

\section{A. Types of Breeding Sites in the Study Area}

A total of 334 mosquitoe breeding sites divided into 24 types were identified during this study. Among the types of breeding sites encountered, we identified : barrels, puddles, ponds, tires, gutters, pits, tanks, buckets, pools, wells, tree holes, abandoned canoes, car carcasses, water-trays, boxes, abandoned lids, cans, bowls, pots, bath-tubes, cement bricks, jars, and car-prints (Fig. 2).

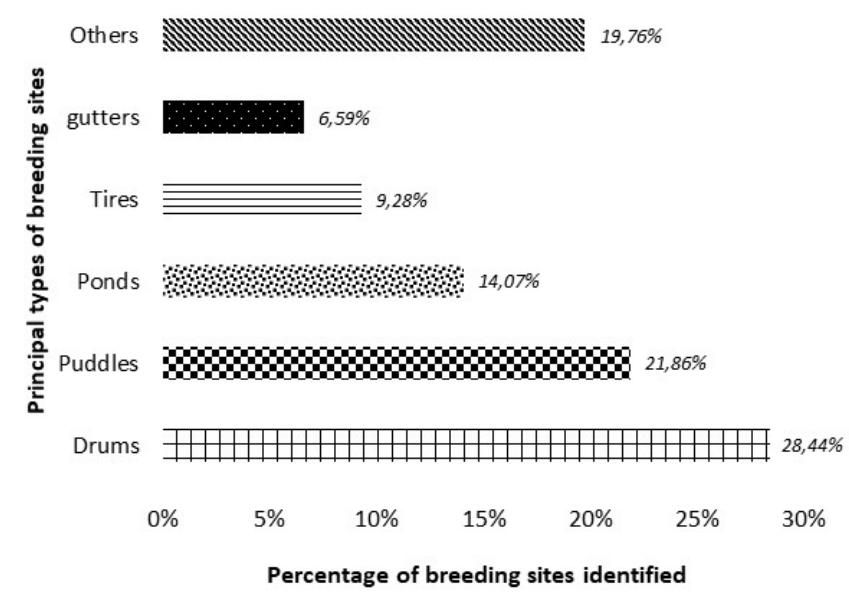

Fig. 2. Types of mosquitoe breeding sites in Akanda and its environs.

Among the identified breeding sites, barrels $(\mathrm{n}=95$; $28.44 \%)$, puddles $(\mathrm{n}=73 ; 21.86 \%)$, ponds $(\mathrm{n}=47 ; 14.07$ $\%)$, tires $(n=31 ; 9.28 \%)$, and channels $(n=22 ; 6.59 \%)$ were the most numerous types of larval habitats (Fig. 2). The other types represented approximately $19.76 \%(n=66)$ of the breeding sites listed in the study area. Most of these mosquitoe breeding places were temporary $(n=244)$, unclear $(\mathrm{n}=205)$, and natural $(\mathrm{n}=204)$ (Table 2$)$.

TABLE 2 : CHARACTERISTICS OF MOSQUITOE BREEDING SITES IN AKANDA AND ITS ENVIRONS

\begin{tabular}{|c|c|c|c|c|c|c|}
\hline & \multicolumn{2}{|c|}{ Seasonality } & \multicolumn{2}{|c|}{ Water aspect } & \multicolumn{2}{|c|}{ Degree of disturbance } \\
\hline & Temporary & Permanent & Clear & Unclear & Natural & Anthropic \\
\hline $\begin{array}{c}\text { Number of } \\
\text { mosquito } \\
\text { breeding sites }\end{array}$ & 244 & 90 & 129 & 205 & 204 & 130 \\
\hline
\end{tabular}

\section{B. Positivity Of Mosquitoe Breeding Sites}

Among the positive breeding sites recorded, 117 harbored Culicinae larvae (74.05\%), 23 harbored Anophelinae (14.56\%), and 18 were Culicinae+Anophelinae (11.39\%) (Fig. 3).

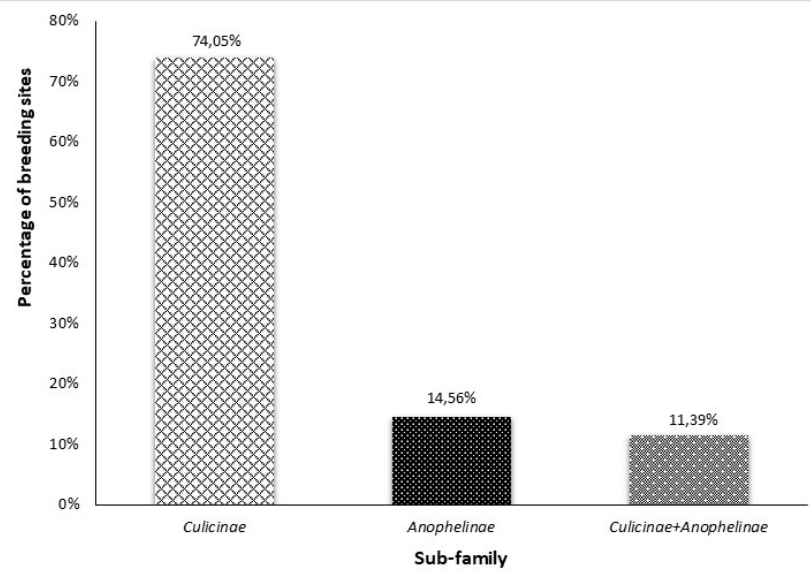

Fig. 3. Proportion of breeding sites in Akanda and its environs.

\section{Spatial Distribution Of Positive Breeding Sites}

Of the 334 larval habitats identified, 158 (47.31\%) were positive, while $176(52.69 \%)$ were negative (Table 3$)$. The maximum number of positive breeding sites identified were recorded at Ecole Nationale des Eaux et Forêts (ENEF) $(n=$ $44)$ and Premier Campement $(n=36)$. The other districts registered less than 20 positive breeding sites and included Okala Carrière $(\mathrm{n}=19)$, Mikoloungou $(\mathrm{n}=18)$, EntracoStade de l'Amitié $(\mathrm{n}=15)$, Sablière $(\mathrm{n}=11)$, Cap Caravane $(\mathrm{n}=8)$, Cités Angondjé $(\mathrm{n}=5)$, and Angondjé Village $(\mathrm{n}=$ 2) (Table 3).

TABLE 3: DisTRIBUTION OF BREEDING SITES IN THE STUDY AREA

\begin{tabular}{lcc} 
Study sites & Number of negative & Number of positve \\
\hline Okala Carrière & 0 & 19 \\
Entraco-Stade de l'Amitié & 0 & 15 \\
Sablière & 13 & 11 \\
Cap Caravane & 22 & 8 \\
ENEF & 70 & 44 \\
Premier Campement & 48 & 36 \\
Cités Angondjé & 9 & 5 \\
Angondjé Village & 0 & 2 \\
Mikoloungou & 14 & 18 \\
\hline Total & $\mathbf{1 7 6}$ & $\mathbf{1 5 8}$
\end{tabular}

\section{Abundance And Distribution Of Mosquitoe Larvae}

During this study, 2,288 mosquitoe larvae were collected, including 1,659 individuals from Culicinae (72.51\%) and 629 specimens of Anophelinae (27.49\%) (Table 4). The Premier Campement was the study site that presented the highest number of larvae $(n=543)$, followed by the ENEF $(n=399)$ and that of Entraco-Stade de l'Amitié $(n=300)$. The rest of the study sites recorded less than 200 larvae (Table 4). 
TABLE 4: ABUNDANCE OF LARVAL POPULATIONS ACCORDING TO THE STUDY SITES

\begin{tabular}{lc}
\hline Study sites & Total number of larvae collected \\
\hline Okala Carrière & 380 \\
Entraco-Stade de l'Amitié & 300 \\
Sablière & 163 \\
Cap Caravane & 150 \\
ENEF & 399 \\
Premier Campement & 543 \\
Cités Angondjé & 47 \\
Angondjé village & 198 \\
Mikoloungou & 108 \\
\hline Total & $\mathbf{2 2 8 8}$ \\
\hline
\end{tabular}

\section{E. Species Richness Of Culicid Fauna}

During this study, eight (8) mosquitoe species including Aedes albopictus, Aedes aegypti, Anopheles gambiae s.l., Anopheles pharaoensis, Culex tigripes, Culex decens, Culex quinquefasciatus, and Mansonia uniformis were identified (Table 5). All these species belonged to 2 subfamilies (Anophelinae and Culicinae) and to 4 genera (Aedes, Anopheles, Culex and Mansonia). The Anophelinae subfamily was represented by two species while the Culicinae subfamily was represented by 6 species (Table 5). The genera Anopheles and Culex were the most species-rich taxa (3 species). The other genera were represented by two species (Aedes) and one species (Mansonia) (Table 5).

TABLE 5 : SPECIES RICHNESS OF THE CULICIDIAN FAUNA IN THE STUDY AREA

\begin{tabular}{|c|c|c|}
\hline Sub-family & Genus & Species \\
\hline \multirow{3}{*}{ Anophelinae } & Anopheles & Anopheles gambiae s.l \\
\hline & Anopheles & Anopheles pharaoensis \\
\hline & S1 & 2 \\
\hline \multirow{9}{*}{ Culicinae } & Aedes & Aedes aegypti \\
\hline & Aedes & Aedes albopictus \\
\hline & S2 & 2 \\
\hline & Culex & Culex tigripes \\
\hline & Culex & Culex decens \\
\hline & Culex & Culex quinquefasciatus \\
\hline & S3 & $\mathbf{3}$ \\
\hline & Mansonia & Mansonia uniformis \\
\hline & S4 & 1 \\
\hline
\end{tabular}

\section{F. Abundance And Distribution Of Adult Mosquitoes}

After the rearing, nearly 1,182 adults were obtained including 444 belonging to the genus Culex (37.56\%), 405 Aedes (34.26\%), 322 Anopheles (27.24\%) and 11 Mansonia (0.94\%). Among these adult mosquitoes, 343 (29.02\%) were collected from Okala Carrière, 277 (23.43\%) from EntracoStade de l'Amitié, 200 (16.92\%) from ENEF, and 161 (13.62\%) from the Sablière. In contrast, all other study sites recorded fewer than 61 adults $(<5.16 \%)$ (Table 6$)$.
TABLE 6: ABUNDANCE OF ADULTS MOSQUITOE ACCORDING TO THE STUDY SITES

\begin{tabular}{ccccc}
\hline Study sites & Anopheles & Culex & Aedes & Mansonia \\
\hline Okala Carrière & 105 & 73 & 161 & 4 \\
\hline Entraco-Stade de l'Amitié & 53 & 74 & 144 & 6 \\
\hline Sablière & 33 & 42 & 85 & 1 \\
\hline Cap Caravane & 20 & 30 & 0 & 0 \\
\hline ENEF & 70 & 115 & 15 & 0 \\
\hline Premier Campement & 20 & 40 & 0 & 0 \\
\hline Cités Angondjé & 10 & 20 & 0 & 0 \\
\hline Angondjé Village & 6 & 30 & 0 & 0 \\
\hline Mikoloungou & 5 & 20 & 0 & 0 \\
\hline Total & $\mathbf{3 2 2}$ & $\mathbf{4 4 4}$ & $\mathbf{4 0 5}$ & $\mathbf{1 1}$ \\
\hline
\end{tabular}

\section{DISCUSSION}

This study identified the different breeding sites of mosquitoes and species diversity in Akanda and its environs. In fact, nearly 334 breeding sites grouped into 24 types have been identified. This multiplicity of mosquitoe breeding sites could be linked to the uncontrolled urban extension, the nonapplication of adequate hygiene measures and the lack of sanitation in the immediate environment of human habitations in the Akanda area. Our results corroborate with those obtained by numerous authors who recorded in various rural and urban localities of Central Africa several mosquitoe breeding sites [13, 17]. Furthermore, these results are similar to those observed by several authors in certain villages and cities in Africa $[23,24,25,26]$. Moreover, the studies conducted by Koumba et al. [17] on mosquitoe larval habitats in the Mouila area, (southern Gabon) showed a large multiplicity of mosquitoe breeding sites.

The breeding sites of Culicinae were the most abundant compared to the other types of positive larval habitats. Indeed, in recent years, the Akanda area, like all other African cities, has undergone various demographic as well as infrastructural changes, marked by anarchic urbanization and high rainfall. All these factors have an impact on the bioecology of Culicinae, thereby favorising the proliferation of the pre-imaginal stages of certain species of the genus Culex and Aedes [13]. Also, these results are similar to those obtained by Koumba et al. [26] in Mouila, in Gabon, and they highlighted that the occurrence of diversified breeding sites could be related to certain factors including demography and human activities.

The abundance of mosquitoes of the genera Culex and Aedes could be due to environmental conditions and anthropic activities, favorable for the proliferation of these taxa. These results corroborate those obtained by several authors who have shown that this sub-family adapts better to the environmental conditions offered by most localities [26, 27]. Furthermore, the abundance of species of the Culicinae sub-family (6 species) is due to the high plasticity of this subfamily in colonizing diversified ecosystems. Excessive household waste, watering activities, and vehicle prints create favourable conditions for the development and maintainance of Culex and Aedes [28, 29]. However, it should be noted that the low presence of mosquitoes of the genera Anopheles and Mansonia is due to the scarcity of their prefered breeding sites. According to Teklu et al. [30], Anopheles spp. prefers sunny natural breeding sites, without vegetation and unpolluted. In contrast, Mansonia larvae are found in water 
collections with aquatic plants such as Pistia spp. and polluted waters [31]. The insufficiency of these two types of larval habitats in the study area could therefore explain the low abundance of these taxa. On the other hand, the presence of certain species including Anopheles gambiae s.l. could constitute a major risk of malaria occurrence in Akanda. Also, preventive measures to control malaria vectors must be developed in this study area.

\section{CONCLUSION}

Although preliminary, the results of this study contribute to the knowledge of the bio-ecology of the culicids fauna of the Akanda area. Also, it appears that the study sites are hosts for the vectors of Plasmodium, filaria, and arboviruses. The breeding sites for these blood-sucking insects are maintained by rain and human activities. Awareness and sanitation campaigns should be conducted in order to educate the local populations on the good practices of the prevention and control of these vectors that cause malaria and other diseases.

\section{ACKNOWLEDGMENT}

We thank the Institute for Research in Tropical Ecology for their technical and logistic support. The authors are grateful to the inhabitants of the Akanda community for their collaboration during the study period.

\section{REFERENCES}

[1] F. Tchoumbougnang, P M. J. Dongmo, M. L. Sameza, E. G. Nkouaya Mbanjo, G. B. Tiako Fotso, P. H. Amvam Zollo, et C. Menut, "Activité larvicide sur Anopheles gambiae Giles et composition chimique des huiles essentielles extraites de quatre plantes cultivées au Cameroun," Biotechnol. Agron. Soc. Environ., vol. 13, no. 1, pp. 77-84, 2009.

[2] WHO, "The world malaria report 2018," World Health Organization, Geneva, pp. 1-210, 2018.

[3] WHO, "The world malaria report 2019," World Health Organization, Geneva, pp. 1-232, 2019.

[4] J. Z. Bi Zahouli, "Anthropogenic impacts on Aedes mosquitoe community dynamics in Côte d'Ivoire," Ph.D. dissertation, University of Basel, Switzerland, pp. 1-173, 2017.

[5] E. M. Bakwo-Fils, P. Ntonga Akono, P. Belong, et J. Messi, "Impact des aménagements piscicoles sur le pullulement culicidien à Yaoundé, Cameroun," Entomologie Faunistique-Faunistic Entomology, vol. 62, no. 3, pp. 109-114, 2010.

[6] F. I. Aigbodion, et O. O. Uyi, "Temporal distribution of and habitat diversification by some mosquitoes (Diptera: Culicidae) species in Bénin city, Nigeria," Journal of Entomology, vol. 10, no. 1, pp. 13-23, 2013.

[7] M. Ikram, A. Chibani, A. Alemad, A. Alkhali, A. Belala, M. Hadji, D. Belghyti, et K. El Kharrim, "Etude écologique et entomologique des gîtes larvaires des Culicidés de la Province de Kenitra (Maroc)," European Scientific Journal, vol. 12, no. 32, pp. 1857- 7431, 2016.

[8] C. Paupy, F. Kassa Kassa, M. Caron, D. Nkoghe, and E. M. Leroy, "A chikungunya outbreak associated with the vector Aedes albopictus in remote villages of Gabon," Vector Borne Zoonotic Diseases, vol. 12, pp. 167-169, 2012.

[9] Minsanté-SNIS, "Annuaire statistique année 2017," Ministère de la Santé de la République Gabonaise, Libreville, Gabon, 337p, 2018.

[10] Minsanté-SNIS, "Carte sanitaire 2017," Ministère de la Santé de la République Gabonaise, Libreville, Gabon, 215p, 2018.

[11] E. M. Leroy, D. Nkoghe, B. Ollomo, C. Nze-Nkoghe, P. Becquart, G. Grard, X. Pourrut, R. Charrel, G. Moureau, A. Ndjoyi-Mbiguino, and $\mathrm{X}$. De Lamballerie, "Concurrent Chikungunya and Dengue virus infections during simultaneous outbreaks, Gabon, 2007," Emerging Infectious Diseases, vol. 15, no. 4, pp. 591-593, 2009.

[12] Minsanté-SNIS, "Mission de collecte des donnés en vue d'une cartographie pour établir un état des lieux, des équipements, des usages et perception des TIC des établissements concernés par le Système National d'Information Sanitaire (SNIS)," Rapport final de mission, Libreville, 139p, 2016.

[13] P. N. Akono, A. Mbida Mbida, P. Awono Ambene, L. Youmbi Enga, Y. A. Kayoum, et S. Kekeunou, "Habitats larvaires et sensibilité des vecteurs du paludisme aux insecticides dans des localités (semi-urbaine et rurale) de la région du littoral camerounais : données préliminaires," Revue d'Ecologie (Terre et Vie), vol. 73, no. 2, pp. 132-141, 2018.

[14] A. Mbouloungou, A. A. Koumba, J. B. Mombo, N. Ndonghan Iyangui, J. F. Mavoungou, et J. Djeki, "Géographie du paludisme dans la région de Libreville-Owendo-Akanda, Gabon," European Scientific Journal, vol. 15 , no. 2, pp. 362-382, 2019.

[15] V. M. T. Mouyalou, "Dynamique morphosédimentaire d'un segment côtier sableux : du Lycée Léon Mba (Libreville) à La Sablière (Baie d'Akouango)," Thèse de Doctorat en Sciences Géographiques. Université Omar Bongo, Libreville, Gabon, 345p, 2017.

[16] DGS-RGPL (Direction Générale de la Statistique du GabonRecensement Général de la Population et des Logements), "Résultats globaux du Recensement Général de la Population et des Logements de 2013 (RGPL, 2013) du Gabon," Libreville, 247p, 2015.

[17] A. A. Koumba, C. R. Zinga Koumba, R. Mintsa Nguema, L. S. Djogbenou, P. Obame Ondo, G. K. Ketoh, P. Comlan, B. M'batchi, et J. F. Mavoungou, "Distribution spatiale et saisonnière des gites larvaires des moustiques dans les espaces agricoles de la zone de Mouila, Gabon," International Journal of Biological and Chemical Sciences, vol. 12, no. 4, pp. 1754-1769, 2018.

[18] A. A. Koumba, C. R. Zinga-Koumba, R. Mintsa-Nguema, P. Obame Ondo, G. Bibang Bengono, P. Comlan, G. K. Ketoh, L. S. Djogbenou, O. Faye, B. M'batchi, et J. F. Mavoungou, "Susceptibilité d'Anopheles gambiae s.s. et An. coluzzii aux organophosphorés et aux carbamates en zones d'exploitation industrielle de palmiers à huile à Mouila, Gabon," Bulletin de la Société de Pathologie Exotique, vol. 111, pp. 176-182, 2018.

[19] M. W. Service, "Irrigation/boom or bane?" In: Service M.W. Demography and vector-borne diseases, CRC Press (eds) Boca Raton, 283-301, 1989.

[20] T. Coffinet, C. Rogier, et F. Pages, "Evaluation de l'agressivité des anophèles et du risque de transmission du paludisme, méthodes utilisées dans les armées françaises," Médecine Tropicale, vol. 69, pp. 109-122, 2009.

[21] A. A. Koumba, C. R. Zinga-Koumba, R. Mintsa-Nguema, L. S. Djogbenou, P. Comlan, M. P. Gneingui, G. K. Ketoh, B. M'batchi, et J. F. Mavoungou, "Détermination de la sensibilité des Anopheles gambiae s.l. à quelques pyréthrinoïdes dans les zones élaéicoles à Mouila (Gabon)," International Journal of Innovation and Scientific Research, vol. 39, no. 2, pp. 110-119, 2018.

[22] F. Baldacchino, et C. Paupy. Clé de détermination des Culicidae présents en Afrique Centrale et au Gabon, Document de travail, IRD/CIRMF, 108 p, 2010.

[23] B. Hayett, D. Fouzia, et S. Noureddine, "Étude systématique et écologique des moustiques (Diptera: Culicidae) dans la région de Tébessa (Algérie)," Entomol. Faunist., vol. 65, pp. 99-103, 2012.

[24] I. Djegbe, A. A. Missihoun, R. Djouaka, et M. Akogbeto, "Surveillance entomologique : Dynamique de la population et de la résistance aux insecticides chez Anopheles gambiae s.l en milieu de riziculture irriguée au Sud Bénin," Journal of Applied Biosciences, vol. 111, pp. 10934-10943, 2017.

[25] F. Diakarida, M. V. B. Jean, G. L. Yao-Acapovi, and S. L. Sevidzem, "Risk of Dengue Transmission in Cocody (Abidjan, Ivory Coast)," $J$. Parasitol. Res., vol. 1, pp. 1-7, 2019.

[26] A. A. Koumba, C. R. Zinga-Koumba, R. Mintsa Nguema, G. K. Ketoh G, S. L. Djogbenou, et J. F. Mavoungou, "Identification et caractérisation des gîtes larvaires des moustiques en saison sèche à la périphérie de la ville de Mouila, Sud du Gabon," Afrique SCIENCE, vol. 16, no. 2, pp. 192-205, 2020.

[27] T. Baldet, "Etude comparative de deux stratégies de lutte contre Culex quinquefasciatus Say, 1823 par Bacillus sphaericus Neide, 1904 dans la ville de Maroua (Nord-Cameroun)," Thèse de Doctorat, Université des Sciences et Technique du Languedoc, Montpellier II, France, 1995.

[28] R. J. A. Assako, D. Bleye, et F. Simard, "Apports des sciences sociales et de l'entomologie dans l'analyse de l'endémicité du paludisme à HEVECAM, une agro-industrie du Sud Cameroun," Geo-Eco-Trop, vol. 29, pp. 101-114, 2005 .

[29] A. Stefani, "Epidémiologie du paludisme et environnement: étude de deux populations amérindiennes de l'est et de l'ouest guyanais," Thèse de Doctorat, Université des Antilles et de la Guyane, 369p, 2011.

[30] B. M. Teklu, H. Tekie, M. McCartney, et S. Kibret, "The effect of physical water quality and water level changes on the occurrence and density of Anopheles mosquitoe larvae around the shoreline of the Koka reservoir, central Ethiopia," Hydrol. Earth Syst. Sci., vol. 14, pp. 2595-603, 2010.

[31] K. N. Vijayakumari, and D. Murali, "Oviposition and larval attachment by Mansonia mosquitoes on host plants," Millennium Zool., vol. 11, pp. 23-7, 2010. 


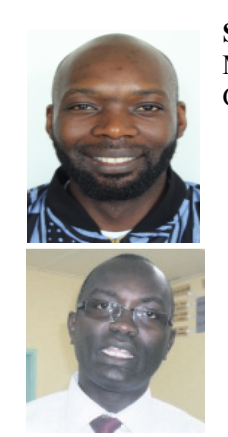

Sevidzem Silas Lendzele: Researcher in Microbiology. BSc Hons (UB, Cameroon), MSc (UDs, Cameroon) (Corresponding author).

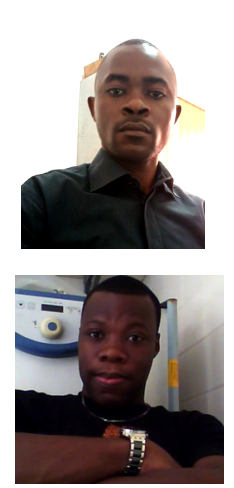

Koumba Aubin Armel: Researcher in Medical and Veterinary Entomology. BSc (UCAD, Senegal), MSc (UCAD, Senegal), PhD (in progress EDSVT-UAC, Benin).

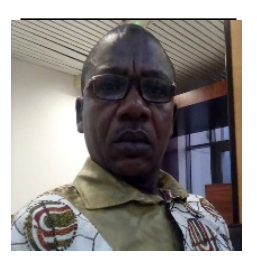

Mbouloungou Alexis: Researcher in Health Geography. BSc (UOB, Gabon), MSc (UOB, Gabon), PhD (in progress UOB, Gabon).

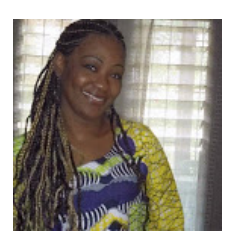

Yacka-Mouele Lauriane: Researcher in Parasitology. BSc (USTM, Gabon), MSc (USTM, Gabon).

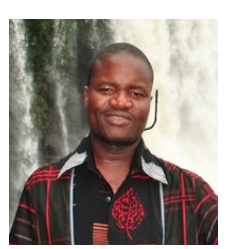

Djogbenou Luc S: Senior Lecturer in Medical Entomology. BSc (UAC, Benin), MSc (UM, France), PhD (UM, France in 2008).

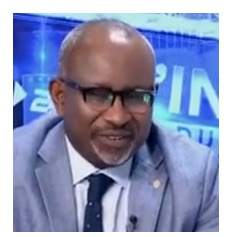

Mavoungou Jacques F: Professor in Medical and Veterinary Entomology. BSc (UM France), MSc (UM France), PhD (UM, France in 2007). 